\title{
Paulo Freire e o legado de uma educação partidária em prol da práxis do oprimido
}

Lucia de Fatima Valente

Professora da Faculdade de Educação da Universidade Federal de Uberlândia (UFU). Atua no curso de Pedagogia e no Programa de Pós-Graduação em Educação na Linha de Pesquisa Estado, Políticas e Gestão em Educação.

E-mail: valentelucia@yahoo.com.br

Thalles Valente de Paiva

Doutorando em Educação no Programa de Pós-Graduação da Faculdade de Educação da UFU, na linha de História e Historiografia. Graduado em História e mestre em História Social na área de Estética e Hermenêutica.

E-mail: thallesvalentep@hotmail.com

Resumo: Este artigo tem como objetivo argumentar a favor de um posicionamento partidário ${ }^{1}$ à educação, a partir da leitura das obras de Paulo Freire, especialmente Pedagogia do oprimido (1987), A importância do ato de ler (1989) e Pedagogia da autonomia (2002). Com o advento do "Escola sem partido" (2014), houve um aumento considerável de materiais que repercutiram as contradições e os antagonismos latentes da educação, difundidos na imprensa e nas redes sociais. Muitas informações são afirmações críticas ao projeto educacional freiriano, declarações que enfatizam uma educação ultrapassada, subjetivista, anárquica e doutrinária política, contrária a uma educação "livre" e "imparcial". Em um giro dialético, este artigo defende que o legado de Freire é e deve ser considerado partidário, que a política está na educação e que nenhum "ponto de vista" é "imparcial", mas parcial na defesa de alguma causa.

Palavras-chave: Paulo Freire; educação; política; legado; práxis.
Abstract: This article aims to argue in favor of a partisan stance regarding education, based on the reading of Paulo Freire's works, especially "Pedagogy of the Oppressed" (1987), "The Importance of the Act of Reading" (1989), and "Pedagogy of Autonomy" (2002). With the emergence of the "School without Party" movement (2014), the number of articles addressing the contradictions and the latent educational antagonisms disseminated both in the press and in social media considerable increased. Several works criticize the Freirian educational project, emphasizing an outdated, subjectivist, anarchic, and politically doctrinaire education that oppose to the "free" and "impartial" education. In a dialectical turn, this article claims that Freire's legacy is and must be considered as being partisan, that politics is inserted in education, and that no "point of view" is "impartial," but rather partial in defense of a certain cause.

Keywords: Paulo Freire; education; politics; legacy; praxis.

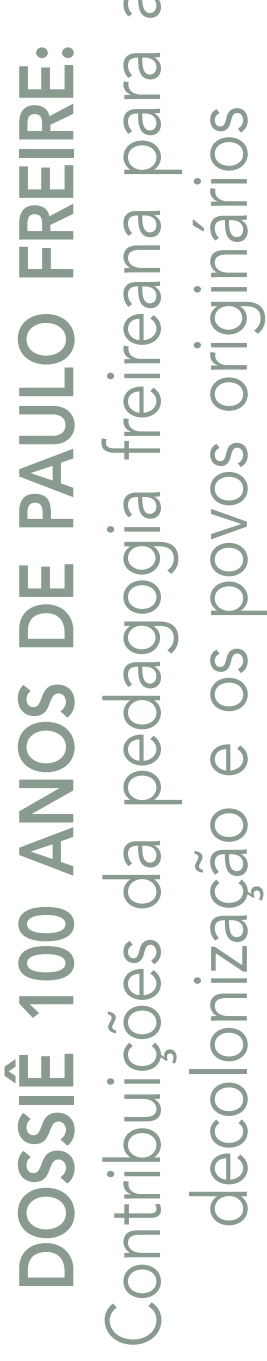

1. Partidário aqui não se limita à criação ou adesão a um partido específico, mas refere-se ao posicionamento parcial do sujeito a um valor, a um projeto de educação e de sociedade. Portanto, é uma forma que nos organizamos para um fim social, seja para defendê-lo, combatê-lo, ou, simplesmente, ser apático à política. A política é algo paradoxal: quanto mais tentamos fugir dela, mais próximos ficamos dela (ver a discussão sobre os winnebagos, trabalhada neste artigo).

Recebido: 31/05/2021

Aprovado: 29/09/2021 


\section{INTRODUÇÃO}

Quando pensamos no centenário de Paulo Freire, espontaneamente nos remetemos ao "reconhecimento" do educador-filósofo. Não nos escapa à consciência que sua pedagogia é reconhecida nacional e internacionalmente. É sabido que sua trajetória circula em torno de lutas e conflitos que não cessam em buscar um "nome próprio" a sua densa biobibliografia. Suas trilhas são escritas e reescritas pelo Outro por meio de tensões que vão desde ativismos $\mathrm{x}$ engajamentos, conflitos x lutas, antagonismos x conflitos, e assim por diante. Tanto o espectro de Freire quanto a apropriação de sua pedagogia circulam no tempo, buscando incessantes significações.

Moacir Gadotti dizia, nos anos 1980, em Convite à Leitura de Paulo Freire ${ }^{2}$, que as repercussões do pensamento freiriano giravam em torno do "idealista", "liberal", "escolanovista popular", "indutivista", "espontaneísta”, "não diretivo", "neoanarquista”, "católico" e até "autoritário”. Na década de 1990, no prefácio da edição italiana da Pedagogia do oprimido, Linda Bimbi ${ }^{3}$ afirmou que Paulo Freire é um autor "inclassificável”. Gadotti, em 2003, admirado pelas palavras de Bimbi, reitera a afirmação da educadora italiana: "Passados mais de 30 anos [da Pedagogia do oprimido], depois de tantos trabalhos publicados por ele e sobre ele, a afirmação [de Bimbi] ainda continua válida"”. Talvez o que Gadotti e Bimbi queiram enfatizar é que não há um conteúdo bruto na pedagogia de Freire que possa ser batizado por um signo estático, e que, em certa medida, sua pedagogia necessita de contextualização dialética no tempo. Dessa maneira, não é de se estranhar que o significante de "inclassificável” vem sofrendo muitos "curtos-circuitos" no "reconhecimento" de sua pedagogia no universo da educação e no seio social desde então.

2. GADOTTI, Moacir. Convite à leitura de Paulo Freire. 2. ed. São Paulo: Scipione, 2004.

3. Ex-freira e educadora italiana. Defensora dos direitos humanos e da pedagogia freiriana, ficou conhecida pela sua luta com os marginalizados e perseguidos pela ditadura de 1964, no Brasil.

4.GADOTTI,Moacir.Porque continuar lendo Freire? Buenos Aires: Clacso, 2003.

\section{O LEGADO DE FREIRE, SEUS DEFENSORES E DETRATORES}

Desde 2012, Paulo Freire é reconhecido pelo Estado como Patrono da Educação Brasileira. Esse título demonstrou um espectro obsceno que está sempre a atormentar as tecituras virtuais da educação - tanto no seu aspecto simbólico (leis e medidas socioeducativas) quanto no imaginário (mitos, sonhos e pesadelos).

O legado de Freire, grosso modo, é reinterpretado por dois grupos antagônicos: os que defendem o legado e os detratores. No primeiro, é possível observar educadores que estão mais interessados no movimento de práxis (reflexão + ação), no engajamento de uma educação que transforma a realidade, sem se esquecer das especificidades de cada contexto. É óbvio que esta posição não escapa das tormentas dos ativismos ou das mitificações vulgares. Há "tentações ideológicas" como o mito da completude, em que se acredita que o educador criou uma forma de educar "completa". Ou, em casos piores, mitificam a persona de Freire, servindo-se da mística fetichista da "santidade", como se ele fosse 
uma "reencarnação" de Santo Antônio de Pádua. Já o grupo dos detratores demoniza seu espírito como algo perverso que desvirtua a "naturalidade" ou "real" dos sujeitos em relação à realidade e, como reacionários, defendem que sua pedagogia é pura "doutrinação" política. Argumentam, ainda, que ela não prepara os estudantes para o mercado de trabalho.

Deveríamos reconhecer que tanto conservadores quanto reacionários foram astutos em sua ação política ao perceberem que os significados de um legado não se restringem apenas ao reconhecimento formal do Estado, mas a como esse espectro vagueia e é significado no seio social. Todavia, não há como não identificar que suas medidas - seus atos na realidade política - por vezes se mantêm nas aparências da "imparcialidade", e outras na resignação e/ou no fatalismo. Como representante de alguns pais e estudantes, Miguel Nagib, em 2014, defendeu o fim da "doutrinação ideológica" com seu anteprojeto "Escola sem Partido". O projeto ganhou popularidade e se alastrou nas câmaras municipais e assembleias até chegar ao Congresso Nacional e ao Senado Federal. Paulo Freire, assim, é caracterizado pelos adeptos do movimento como o "baluarte" da "doutrinação marxista", e sua pedagogia tem como objetivo final influenciar as mentes de jovens e crianças ao "comunismo" e às inúmeras "depravações" esquerdistas. Nagib enfatizou que:

O que a gente defende é que alguns dos ensinamentos de Paulo Freire se chocam com a Constituição. Nossa crítica é de natureza jurídica porque o uso da sala de aula para efeito de transformação da sociedade, como ele defendia, dependendo da maneira com que isso é aplicado, viola a liberdade dos alunos e a neutralidade política e ideológica do Estado ${ }^{5}$.

Porventura, o que mais nos impacta, neste discurso, é sua forma distorcida e ambígua. De acordo com Penna ${ }^{6}$, o "Escola sem Partido" utiliza-se de linguagem próxima ao senso comum, simplificando questões complexas por meio de memes - imagens acompanhadas de breves dizeres. Desta simplificação, utilizam-se quatro formas de ativismos: a primeira é uma concepção vulgar de escolarização; a segunda, uma desqualificação do professor (professor é um manipulador ideológico, um vampiro); a terceira compreende estratégias fascistas (piadas opressivas às minorias e memes ofensivos às figuras de Paulo Freire e Gramsci); e a quarta, o poder total dos pais sobre o filho (temor ao Estado). Sua missão é instalar um "clima de denuncismo" e um "discurso de ódio".

Assim, o movimento age a fim de esvaziar o discurso (tecitura simbólica que medeia a realidade) da experiência de realidade do sujeito (experiência sensível), criando narrativas fantasiosas (rumores, suposições, teorias conspiratórias etc.) que estão para além da realidade vivida e sentida. O que marca este processo ideológico é, portanto, a suspensão dos critérios de verdade, ou seja, o "Escola sem Partido" coparticipa dos mecanismos da "pós-verdade" política, "a crença em afirmações 'sentidas como verdadeiras', mas que não têm nenhuma base nos fatos". "São inverdades reproduzidas, curtidas, compartilhadas nas redes sociais ${ }^{7}$."
5. SOUZA, Marcele; TOLEDO, Giuliana de. Legado de Paulo Freire é defendido por uns e odiado por outros. Revista Galileu Rio de Janeiro, 2 maio 2017. Disponível em: https://re vistagalileu.globo.com/Revista/noticia/2017/05/legado-de-paulo-freire-e-defendido-por-uns-e-odiado-por-outros.html\#: :tex$\mathrm{t}=\% \mathrm{E} 2 \% 80 \% 9$ CTudo\%20 que $\% 20$ a $\% 20$ gente $\% 20$ faz,\%E2\%80\%9D\%2C\%20 orgulha-se\%20Nogueira. Acesso em: 28 abr. 2021.

6. PENNA, Fernando de A A escola sem partido como chave do fenômeno educacional. In: FRIGOTTO Gaudêncio (org.). Escola "sem" partido: esfinge que ameaça a educação e a sociedade brasileira. Rio de Janeiro: LPP/ UERJ, 2017. p. $35-48$

7. 'ECONOMIST' critica a era da 'pós-verdade' na política. O Globo, Rio de Janeiro, 8 out. 2016. Disponível em: https:// oglobo.globo.com/brasil/ economist-critica-era-da- pos-verdade-na-politica-20258867. Acesso em: 27 out. 2021 


\section{comunicação \& educação • Ano XXVI • número 2 • jul/dez 2021}

8. Isto não nos lembra a adaptação fatalista do positivismo? O grosso da herança positivista (como sua proposta de educação) parte de sistematizações conceituais e axiológicas das quais a sociedade é regida por "leis naturais", invariáveis, que independem da vontade e da ação humana. A justificativa positivista, nas ciências humanas, como nos afirma Löwy, está alicerçada na objetividade "positiva da realidade" social, i.e., supressão da negatividade política. Como a sociedade é um dado "natural", sublinham Durkheim e Comte, seus principais representantes, que as doutrinas "positivas" são conservadoras, já que contrapõem a qualquer mudança radical na sociedade: "nosso método não tem pois nada de revolucionário; ele é mesmo, num certo sentido, essencialmente conservador". "Não é por menos que Comte afirmou que o positivismo "tende profundamente, por sua natureza, a consolidar a ordem pública pelo desenvolvimento de uma sábia resignação". DURKHEIM 1975 apud LÖWY, Michael. Marxismo contra positivismo. São Paulo: Cortez, 2018, p. 15; COMTE, 1949 apud ibidem, p. 13.

9. SAVIANI, Demerval. A crise política no Brasil, o golpe e o papel da educação na resistência e na transformacão. In: LUCENA, Carlos: PREVITALI, Fabiane Santana; LUCENA Lurdes. A crise da democracia brasileira Uberlândia: Navegando, 2017. p. 215-232, p. 231.
No entanto, neste discurso ambíguo, outro espectro grosseiro se apresenta como uma espécie vulgar de "positivismo social", um "retorno" ao Brasil dos anos 1960, no qual a educação deve restringir-se a ser meramente tecnicista e formal. Um discurso que pressupõe que o sujeito, em relação à construção do saber, deve-se reduzir a zero, visto que o resultado obtido deve se repetir em qualquer contexto. A realidade social é uma "coisa" que deve ser instrumentalizada, assim como os objetos das ciências naturais, de forma que o produto do saber se apresenta como algo "imparcial", restando aos envolvidos a conformidade da descoberta. O que se apresenta, também, no discurso da "Escola sem partido" é que a realidade é "positiva" e, assim, tanto os sujeitos quanto a educação devem se sujeitar a esta ${ }^{8}$.

Precisamos ficar atentos a esse caráter positivo da realidade defendida pelos antagonistas da educação transformadora. A remoção do negativo não leva em consideração o contexto da estrutura social e sua negação: a crítica ética. Em outras palavras, estudantes, professores e pesquisadores fazem parte de uma realidade social e estão diretamente relacionados a um Outro; um Outro que não é natural, mas sim, não natural. Os sujeitos, em suas relações sociais, não estão em harmonia como se cada indivíduo fizesse parte de um todo orgânico e conciso; de maneira oposta, os papéis, que são dados e/ou reconhecidos pelo Outro (classe, etnia e gênero), sofrem "curtos-circuitos" de suas particularidades que não se reconhecem aos papéis que lhe foram concedidos. A realidade social não é um dado "natural", pelo contrário, ela é tensionada pela ação humana, sendo transgredida, construída e significada historicamente.

Logo, a posição ideológica da "Escola sem Partido" não é uma posição neutra, apolítica, mas uma legitimação estritamente política ao status quo, conforme aponta Saviani. Para o autor,

[...] a proposta da escola sem partido se origina de partidos situados à direita do espectro político com destaque para o PSC (Partido Social Cristão) e PSDB (Partido da Social-Democracia Brasileira) secundados pelo DEM (Democratas), PP (Partido Popular), PR (Partido da República), PRB (Partido Republicano Brasileiro) e os setores mais conservadores do PMDB (Partido do Movimento Democrático Brasileiro). Como se vê, a "escola sem partido" é a escola dos partidos da direita, os partidos conservadores e reacionários que visam manter o estado de coisas atual com todas as injustiças e desigualdades que caracterizam a forma de sociedade dominante no mundo de hoje ${ }^{9}$.

De outro modo, pode-se dizer que é uma mitificação do positivo, ou aquilo que Freire costumava chamar de "fazer puro", entendido como uma abstração fetichista que elimina as contradições e os antagonismos que cortam a realidade. Nesse ponto, é importante rememorar seus ensinamentos, porque a educação não é um saber que anula a política; ao contrário, ela está ontologicamente inclusa em sua práxis porque a política, longe de ser um dado "natural", é um ato de escolha. Freire afirma que: 
Do ponto de vista crítico é tão impossível negar a natureza política do processo educativo, quanto negar o caráter educativo do ato político. Isto não significa, porém, que a natureza política do processo educativo e o caráter educativo do ato político esgotem a compreensão daquele processo e deste ato. Isto significa ser impossível; de um lado, como já salientei, uma educação neutra, que se diga a serviço da humanidade, dos seres humanos em geral; de outro, uma prática política esvaziada de significação educativa. Neste sentido é que todo partido político é sempre educador e, como tal, sua proposta política vai ganhando cerne ou não na relação entre os atos de denunciar e de anunciar. Mas é neste sentido também que, tanto no caso do processo educativo quanto no do ato político, uma das questões fundamentais seja a clareza em torno de a favor de quem e do $q u \hat{e}$, portanto contra quem e contra o quê, fazemos a educação de a favor de quem $e$ do quê, portanto, contra quem e contra o quê, desenvolvemos a atividade política. Quanto mais ganhamos esta clareza através da prática, tanto mais percebemos a impossibilidade de separar o inseparável: a educação da política. Entendemos então, facilmente, não ser possível pensar, sequer, a educação, sem que se esteja atento à questão do poder ${ }^{10}$.

Talvez um bom exemplo sintético sobre ato político freiriano, o ato de escolha em frente à tensão Real na realidade, seja a análise de Lévi-Strauss, em Antropologia estrutural, sobre a construção espacial dos winnebagos, uma tribo dos Grandes Lagos norte-americanos. Relata-se que os "winnebagos se dividiam antigamente em duas metades, chamadas wangeregi, ou 'os do alto', e manegi, ou 'os que estão na terra', que chamaremos doravante, por comodidade, 'os de baixo ${ }^{11}$ "'. O interessante é que quando pediram para descrever a planta da aldeia, o resultado do relato foi bem diferente - dependendo de qual subgrupo o sujeito fazia parte. Os dois grupos percebem a aldeia como um grande círculo; no entanto, para o subgrupo ("os de baixo") existe mais um círculo de casas centrais dentro desse grande círculo, enquanto para o outro subgrupo (“os do alto"), o grande círculo é cortado no meio por uma clara linha divisória12.

Podemos usar esse relato como um exemplo interessante para problematizarmos a lacuna real que fere a práxis educativa. É possível pensar o subgrupo "os de baixo" como "conservadores" (ato resignado), que compreendem o plano da aldeia como um círculo de cabanas que estão mais ou menos simetricamente organizadas em torno de um centro de harmonia: o templo sagrado; e "os do alto", como seu "opositor crítico" (ato revolucionário), que percebem a aldeia como dois agrupamentos distintos, separados por uma fronteira invisível, na qual existe uma tensão de desigualdade entre as duas extremidades. Aqui, deveríamos ficar atentos à afirmativa de Lévi-Strauss, ele não nos incentiva a cairmos na "neutralidade" do conhecimento, ou muito menos no relativismo cultural em que a percepção espaço social depende do lugar do observador e/ou subgrupo: a clivagem dos pontos de vistas relativos esconde uma verdade que não está na organização objetiva das cabanas, mas no núcleo Real de um antagonismo que os habitantes da aldeia não conseguem simbolizar, explicar o porquê desse desequilíbrio social que os acomete.
10. FREIRE, Paulo. A importância do ato de ler. Cortez. São Paulo, 1989, p. 15-16.

11. LÉVI-STRAUSS, Claude. Antropologia estrutural. São Paulo: Cosac Naify, 2008, p. 148.

12. Ibidem.

13. ŽIŽEK, Slavoj. A marioneta e 0 anão: 0 cristianismo entre perversão e subversão. Lisboa: Relógio d'Água, 2006, p. 97.

14. Ibidem, p. 16. 
O ponto central que queremos propor com o exemplo de Lévi-Strauss é que o conhecimento e o posicionamento do sujeito em relação à realidade não estão cravados em uma "neutralidade", ou em apenas "jogos de aparências". Há um Real, e esse não é uma Coisa inacessível, mas a distância que acomete o nosso acesso a essa Coisa, o antagonismo que se apresenta em nossa realidade, aquilo que retorce a sua urdidura - esta é a verdade do Real. Por isso, a verdade, como nos ensina Žižek, "não é o estado 'real' das coisas, isto é, a visão 'directa' do objecto sem perspectiva deformadora, mas o próprio Real do antagonismo que causa a perspectiva deformadora" ${ }^{13}$.

Portanto, o lugar da verdade não é a maneira como as coisas se apresentam diretamente para nós, ou como as coisas são realmente em si mesmas, mas a distância que separa uma perspectiva da outra. No caso de uma sociedade de classes, seu Real não está nos "pontos de vista de cada classe", mas no antagonismo que corta a relação social, que torna os dois "pontos de vista" radicalmente incomensuráveis. O mesmo pode ser dito sobre "os pontos de vista" da educação e estes estão diretamente ligados ao antagonismo. Esse Real que deforma os "pontos de vista" é causa da impossibilidade de alcançar uma visão "neutra" da realidade. Perante essa lacuna que fere a realidade, o conhecimento tem um caráter partidário.

Ora, quando Paulo Freire diz que, "do ponto de vista crítico, é tão impossível negar a natureza política do processo educativo quanto negar o caráter educativo do ato político", ele não está se referindo à distância paradoxal que separa um "ponto de vista" do Outro? Ou seja, o Real da educação, como ato político, é a distância que separa uma perspectiva da outra. O ato de inserir uma forma de educar já é um posicionamento parcial em relação ao antagonismo do Real. Quando Freire costumava comentar sobre a educação burguesa, ele dizia: "a educação burguesa, a que criou ou enformou a burguesia, mas a burguesia que, chegando ao poder, teve o poder de sistematizar a sua educação"14. Antes do processo revolucionário burguês, os "pontos de vista" antagonizavam-se entre a burguesia e a aristocracia - essa, como classe antagônica da classe dominante, não poderia, mediante ao seu posicionamento perante o poder, esperar que as elites pudessem pôr em prática modelos educacionais que lhes interessavam.

A educação está ligada ao poder e este está sempre a sofrer a tensão antagônica. De outra maneira, a burguesia antes da tomada do poder germinava e compartilhava seus frutos no seio da aristocracia, e, com a ruptura, logo passou de contestadora a dominadora. Entretanto, deveríamos ter em mente que o ato do pensamento crítico não é apenas ser a nova entidade contestatória, mas o de afirmar que o antagonismo é o Real traumático da realidade. Contrária às aparências de uma suposta "neutralidade", a pedagógica crítica entende a educação como engajamento político, engajamento aos excluídos e aos oprimidos da polis:

Não junto a minha voz à dos que, falando em paz, pedem aos oprimidos, aos esfarrapados do mundo, a sua resignação. Minha voz tem outra semântica, tem outra música. Falo da resistência, da indignação, da "justa ira" dos traídos e dos 
enganados. Do seu direito e do seu dever de rebelar-se contra as transgressões éticas de que são vítimas cada vez mais sofridas ${ }^{15}$.

Ora, não podemos nos espantar, ou não nos atrevermos em dizer que tanto os antagonistas, quanto aos que enveredam na pedagogia crítica de Paulo Freire são partidários. Quando dizemos que Paulo Freire é "inclassificável”, isso não quer dizer que fugimos para a neutralidade, ou para os relativismos (tão caros ao nosso tempo); ao contrário, isso quer dizer que há um Real, uma deformidade que não permite uma estática e homogênea ontologia de um nome próprio ao legado freiriano, pois não há signo que inercie o pensador no tempo. Mas esse corte no signo revela a nós a sua incompletude, que permite agirmos na realidade, seja pela via do ativismo ou do engajamento, que não é de maneira nenhuma "apartidária”, mas política. O "inclassificável” é aquilo que permite que o legado de Freire seja significado de forma partidária em meio aos antagonismos do nosso tempo presente.

É por esta razão que não deveríamos cair na tentadora sedução, de Gadotti, do legado da completude, destacando em suas rememorações que: "Paulo Freire foi um ser humano completo. Doce guerreiro das palavras, visionário, acreditava na importância da escola, do saber, da palavra, da cultura, do educador"16. $\mathrm{Na}$ verdade, deveríamos dizer o contrário, porque exatamente por ser um ser humano incompleto, é que ele pode ter sido não tudo isso. Esse não todo está ligado à abertura do ser. Somente por ser incompleto, Freire pôde lutar, ter a liberdade de ser partidário de uma educação transformadora; caso ele fosse completo, estaria em completude ${ }^{17}$ com a sua realidade (em harmonia com o "normativo" burguês), e não em negação - aberto a transformá-la: "não haveria existência humana sem a abertura de nosso ser ao mundo" "18. Só é aberto à mudança o "incompleto", e ser ser humano em Freire, é ser inconcluso:

Repito, porém, como inevitável, a franquia de mim mesmo, radical, diante dos outros e do mundo. Minha franquia ante os outros e o mundo mesmo é a maneira radical como me experimento enquanto ser cultural, histórico, inacabado e consciente do inacabamento. Aqui chegamos ao ponto de que talvez devêssemos ter partido. O do inacabamento do ser humano. Na verdade, o inacabamento do ser, ou sua inconclusão, é próprio da experiência vital. Onde há vida, há inacabamento. Mas só entre mulheres e homens o inacabamento se tornou consciente ${ }^{19}$.

A consciência é, portanto, o processo por meio do qual o ser toma consciência do seu próprio inacabamento. A tomada de consciência, no entanto, não é nada fácil. Freire sempre dizia que o nascimento do sujeito crítico é um verdadeiro parto. No princípio, o sujeito crê que é Um com Outro, preso na crença que ser e Outro estão em completude, ou seja, que sua identidade (os predicativos reconhecidos pelo outro) é uma marca "real" de sua existência (sua essência). Acometido por essa marca real, o sujeito cai resignado perante a normatividade da realidade. A esta resignação Freire chamava de fatalismo, introjeção de uma sujeição dócil perante o Outro. De tanto ouvir que é incapaz,
15 FREIRE. Paulo. Pedagogia da autonomia: saberes necessários à prática educativa. São Paulo: Paz e Terra, 2002, p. 52.

16. GADOTTI, Moacir. O IPF e o legado de Paulo Freire. Revista de Ciências da Educação, Lorena, v. 2, n. 3, p. 231-241, 2000, p. 2.

17. Mesmo que o discurso de Gadotti talvez tenha o intuito de ter um caráter estritamente estético formal, expressar a beleza da pessoa de Freire, e não que seu conteúdo era de fato completo, contudo, pensamos que não deveríamos utilizar a palavra completo, exatamente pela virada da estética moderna em que forma e conteúdo estão em tensão, ou no "ponto de vista" dialético, como dizia Hegel: "relação absoluta do conteúdo e da forma [...], a conversão de uma na outra, de sorte que o conteúdo não é nada mais que a conversão da forma em conteúdo, e a forma não é nada mais que a conversão do conteúdo em forma". HEGEL. s/d apud SZONDI, Peter. Teoria do drama moderno. São Paulo, Cosac Naify, 2001, p. 24.

18. FREIRE. Paulo. Pedagogia da... Op. cit., p. 45.

19. Ibidem, p. 26. 
que não sabe nada, que não pode saber, que é enfermo, indolente, que não produz em virtude de tudo isto, termina por se convencer de sua incapacidade ${ }^{20}$ ).

Todavia, essa identidade (sendo uma apropriação hegeliana de Freire) é uma mera mistificação fetichista, um mito unitário de submissão, na qual o escravo, pelo medo da morte, subjuga-se ao senhor. Fetichista porque o ser e o Outro, no processo dialético, frustram-se na tentativa de se conciliarem em completa harmonia; o Outro, entendido como a intersubjetividade (tecitura normativa da realidade), e a negatividade radical do ser (o particular), não se adéquam em completude, mas embatem-se em distorções, faltas, antinomias e antagonismos. Perante estas distorções reais, o poder hegemônico se utiliza de mecanismos ideológicos dos quais narrativas que tentam organizar essa fissura traumática pela via do "mito resignatório" são criadas. O reconhecimento do destino para os camponeses era pela via da significação fatalista, dizia Freire em sua jornada de apreender e ensinar no Chile. Eles não tomavam a consciência porque estavam fixados na crença fictícia da inexorabilidade do Outro:

Quase sempre este fatalismo está referido ao poder do destino ou da sina ou do fado - potências irremovíveis - ou a uma distorcida visão de Deus. Dentro do mundo mágico ou místico em que se encontra a consciência oprimida, sobretudo camponesa, quase imersa na natureza, encontra no sofrimento, produto da exploração em que está, a vontade de Deus, como se Ele fosse o fazedor desta "desordem organizada"

Uma das características desta fixação é o "fechamento do ser" em que o sujeito se fecha para o mundo, resguardando o "em si", na tentativa de salvaguardar um identitarismo místico de totalidade. O sujeito resignado pressupõe que a realidade é um dado natural, e, assim, se aliena, de forma passiva, aos dispositivos do poder hegemônico. Sua relação com o mundo é apenas de ser um simples espectador passivo e o mundo é uma Coisa intocável, um Todo sem relação com si. No entanto, ao ser tomado pela consciência de si, a realidade que antes se apresentava como completa, agora se apresenta como incompleta. Daí o fundamento que a consciência, em sua reviravolta crítica, vem a ser não mais um fechamento de uma "adequação" ao Outro, mas uma abertura que problematiza a sua própria adequação. A consciência ingênua, que antes estava fechada em si (posição da qual a realidade é regida por uma identidade fechada em sua totalidade) vai de encontro à radicalidade do para si (posição em que sujeito está em tensão com a realidade inacabada). A realidade, que era mistificada como a Coisa natural, agora é encarada como um composto artificial, repleto de fissuras construídas no tempo de forma partidária ao Outro.

20. Idem. Pedagogia do oprimido. 17. ed. Rio de Janeiro: Paz e Terra, 1987.

21 Ibidem, p. 31.

\section{NA DEFESA DE UMA CAUSA}

O posicionamento de uma "educação crítica" carrega consigo essas pressuposições segundo um posicionamento em frente aos antagonismos do Real. Esta jamais se renderá, de maneira passiva, à suposta "neutralidade política 
e ideológica do Estado", defendida pelos ideólogos do "Escola sem partido"; a responsabilidade do "educador crítico" é com a radicalidade do ato ético, ética entendida como crítica da condição de realidade do educando. A postura do "educador crítico" não está inclinada às artimanhas da "doutrinação ideológica" para atingir objetivos ocultos sórdidos. $\mathrm{Na}$ verdade, seu desejo está mais para os caminhos que intentam à "educação como prática da liberdade": liberdade que não é dada, ou intrínseca ao sujeito, mas sim, orientada como falta e por meio da qual só tomamos consciência da liberdade quando estamos em sua busca. De maneira moderna, Freire enfatizou que:

Ninguém tem liberdade para ser livre: pelo contrário, luta por ela precisamente porque não a tem. Não é também a liberdade um ponto ideal, fora dos homens, ao qual inclusive eles se alienam. Não é ideia que se faça mito. É condição indispensável ao movimento de busca em que estão inscritos os homens como seres inconclusos ${ }^{22}$.

Numa estrutura social na qual a mediação da realidade é feita pelos interesses da burguesia, o conteúdo de seu modelo educacional exclui e reprime aquilo que não é de seu interesse. É nessa exclusão que aparece a liberdade e é nas fissuras dos seus aparatos ideológicos, naquilo que lhe falta, que está o caminho para a emaciação. A forma da pedagogia crítica está na práxis de sinalizar aquilo que foi excluído do discurso hegemônico. Ora, o que foi excluído da problematização, evidentemente, foram os aparatos de opressão.

Também não podemos ser inconsequentes e esquecermo-nos do fardo da posição oprimida e como esta está sendo significada no nosso presente. É evidente que atualmente a palavra "oprimido" vem passando por um processo de "achincalhamento", sofrendo ataques constantes, cujo objetivo final é a perda de sua práxis emancipatória, suas potencialidades radicais em contraposição à política hegemônica. Grande parte disso vem das redes sociais, pelo compartilhamento de "memes" e notícias, principalmente pelos adeptos das políticas do "Escola sem partido" e criou-se o imperativo da desqualificação, ou seja, o dever de vulgarizar a condição de oprimido. Sua forma de atuação se ampara na tentativa de excluir o trauma do antagonismo político do debate público e qualquer discurso que coloca ênfase nesta condição é "mimimi” (objeção sem sentido). Assim, aquele que está sofrendo opressão não pode reivindicar uma nova posição de reconhecimento ao Outro e somente é exequível a troca de posição pela via do mérito normativo e, caso o mérito falhe, a resposta é ainda mais cínica: "a realidade é assim. Contente-se e seja forte" ${ }^{23}$.

Quando o discurso não é pela via da resignação, ele trabalha no descomprometimento entre a palavra e a realidade ${ }^{24}$, o sujeito pode gozar da "liberdade" de dizer as palavras livremente desde que essas não tragam nenhum atrito com a realidade. Como a imprensa e seu discurso de "liberdade de expressão", que nos bombardeiam com o marketing da "opressão" e da "não opressão", desde que não signifique uma desconfiguração da estrutura de classe - as palavras podem circular no seio social, mas jamais podem se

22. Ibidem, p. 22

23. Isto não está explícito no discurso de parabéns às mulheres de Jair Bolsonaro? "No dia 8 de março de 2017, o então deputado Jair Bolsonaro gravou o seguinte comentário para o Dia da Mulher: 'Parabéns a todas as mulheres do Brasil, porque eu defendo a posse de armas de fogo para todos. Inclusive vocês, obviamente, as mulheres. Nós temos de acabar com o 'mimimi'. Acabar com essa história e de feminicídio, que, daí, com arma na cintura, vai ter é homicídio". De maneira dialética podemos observar o desenvolvimento ideológico do enunciado de Bolsonaro. Enquanto - "mimimi" é a subversão negativa referente à cultura do machismo (feminicídio), - discurso do Bolsonaro funciona como a "negação da negação" à subversão da alteridade feminina, i.e., ele nega a negação do oprimido, mantendo o conteúdo positivo da estrutura de dominação, "intacto". A mulher continuará presa à estrutura simbólica de opressão com a possibilidade de se defender pela defesa armada, o que significa, no final, uma mera "adaptação" à violência. De outro modo, Bolsonaro não está propondo acabar com o feminicídio, mas, sim, com o "mimimi" ("Nós temos de acabar com o'mimimi'") e, a partir, deste problema Real (agatonismo), fazer propaganda (partidária) ao armamentismo. IACONNELLI, Vera. Risco mimimi em números. Folha de S.Paulo, São Paulo, 9 abr. 2019. Disponível em: https://www1.folha.uol.com. $\mathrm{br} /$ colunas/vera-iaconelli/2019/04/risco-mimimi-em-numeros.shtml. Acesso em: 15 abr. 2021.

24.ŽIŽEK, Slavoj. Um mapa da ideologia. Rio de Janeiro: Contraponto, 1996. 
25. A página "Bolsonaro opressor 2.0" estava em processo de investigação (sobre contas falsas) pelo Laboratório Forense Digital (DFRLab). A investigação apontou uma possível ligação de um assessor do presidente Bolsonaro, Tercio Arnaud Tomaz, como administrador de alguns dos perfis que divulgavam fake news. Ele também é um dos integrantes do chamado 'gabinete do ódio'. INVESTIGAÇÃO aponta assessor de Bolsonaro como responsável por página de fake news derrubada pelo Facebook. G1 Rio de Janeiro, 8 jul. 2020. Disponível em: https://g1. globo.com/economia/tecnologia/noticia/2020/07/08/ investigacao-aponta-assessor-de-bolsonaro-como-responsavel-de-pagina-de-fake-news-derrubada-pelo-facebook.ghtml. Acesso em: 27 out. 2021.

26 Freire costumava citar o exemplo de oprimidos que lutavam pela reforma agrária, não para libertarem-se, "mas para passar a ter terra e, com esta, tornar-se proprietários ou, mais precisamente, patrões de novos empregados". Podemos acrescentar mais exemplos, maridos que sofrem jornadas exorbitantes de trabalho, voltam para casa e descontam suas frustrações (a opressão do mundo do trabalho) na mulher e, em casos mais extremos, partem para a violênciafísica; ou alunos que sofrem bullying na escola, e, ao retornarem à "cybervida", visitam fórunse compartilham "memes" de "opressão descontraída", a fim de sedar suas angústias pela via "bullying digital". Casos mais extremos de revolta contra bullying são quando eles saem do campo das fantasias (quando oprimido cria cenas de vingança em sua cabeça, ou simplesmente goza delas em cenários virtuais [fóruns e páginas] na internet) e partem para ação real. 0 caso mais recente no Brasil é o massacre de Suzano, em 2019. FREIRE, Paulo. Pedagogia do... Op. cit., p. 21.

27. FREIRE, Paulo. Pedagogia do... Op. cit., p. 21. materializar em atos. Também é possível observar mais uma outra forma, um cinismo que talvez seja ainda mais obsceno pois, a afirmação, que antes era mantida nas aparências, é agora escancarada. Se antes o opressor dizia que isso era "mimimi", mantendo seus interesses hegemônicos encobertos, agora os afirma e os admite de maneira irônica: "Sim, somos opressores, e daí!?" Nas redes sociais é possível encontrar variadas páginas de "extrema direita”, que admitem sua "opressividade" e são compartilhadas. Títulos como "O opressor", "Conservador opressor", "Macho opressor", "Macho Opressor e Patriarcal", "Capitalismo opressor", "Bolsonaro Opressor 2.0”25, entre outras. São páginas que têm como objetivo propagar, de maneira "irônica" e "descontraída" a "opressão" do "mundo branco", "conservador", "machista" e "capitalista".

Isto não nos lembra a assertiva de Freire (1987) de que, em uma estrutura opressiva, existe uma distorção do ser para o ser menos? O ser preso às coordenadas do Outro deseja o desejo do Outro, e, assim, herda os ideais de seu senhor. Quando o ser se torna sujeito à cultura, caso ele testemunhe a opressão como ideal de ser, ele tende a desejar a opressividade. A aderência ao opressor é objetificação ao gozo do opressor. O oprimido não deseja destruir a opressão, mas articulá-la a seu favor, gozá-la de seus mecanismos - mesmo que sejam meras partículas de gozo ${ }^{26}$. Acerca da imersão ao gozo do Outro, o educador salientava que:

Nestas circunstâncias, não chegam a "admirá-lo", o que os levaria a objetivá-lo, a descobri-lo fora de si. Ao fazermos esta afirmação, não queremos dizer que os oprimidos, neste caso, não se saibam oprimidos. O seu conhecimento de si mesmos, como oprimidos, se encontra, contudo, prejudicado pela "imersão" em que se acham na realidade opressora. "Reconhecer-se" a este nível, contrário ao outro, não significa ainda lutar pela superação da contradição. Daí esta quase aberração: um dos polos da contradição pretendendo não a libertação, mas a identificação com o seu contrário ${ }^{27}$.

Desta maneira, não é de se estranhar que essas páginas que infernizaram as redes sociais infestando-as de "memes" obscenos, gozam do resto de opressão do seu mestre. Quanto mais alienados à opressão, mais irão querer gozar de seus dispositivos, como uma espécie de "servidão voluntária" que, ao reconhecer a superioridade do seu mestre, irão cada vez mais mimetizar a sua ação, estabilizando a realidade, assim criando uma camada fictícia de "naturalidade". Portanto, este discurso ideológico projeta na assertiva que não existe na nossa cultura brasileira capitalista opressores e oprimidos, mas indivíduos livres que escolhem seus próprios caminhos. Capitalismo, machismo, racismos etc. são traços do real e fazem parte da natureza humana e não são intrínsecos à realidade da cultura presente.

É bom deixarmos claro que, aqui, não estamos repetindo o discurso do "Escola sem partido" e seus antagonistas da pedagogia libertadora de maneira reversa. Não é que o discurso opressivo da cultura simplesmente doutrina o ser à opressão, ou que os mecanismos permissivos capitalistas seduzem os "ingênuos" e "impotentes" oprimidos. Ao contrário, são os oprimidos que hospedam 
em si o "parasita" da opressão. Caso defendêssemos esta assertiva cairíamos em contradição, despencaríamos no fatalismo e no erro grosseiro e elitista de subestimar as potencialidades dos oprimidos. O sujeito freiriano está aberto à responsabilidade da liberdade, pois,

Somente na medida em que se descubram "hospedeiros" do opressor poderão contribuir para o partejamento de sua pedagogia libertadora. Enquanto vivam a dualidade na qual ser é parecer e parecer é parecer com o opressor, é impossível fazê-lo. A pedagogia do oprimido, que não pode ser elaborada pelos opressores, é um dos instrumentos para esta descoberta crítica - a dos oprimidos por si mesmos e a dos opressores pelos oprimidos, como manifestações da desumanização ${ }^{28}$.

É esta a virada dialética radical da educação em Freire que os detratores, aparentemente, não entenderam. E é a este insight de Freire que devemos nos atentar. $\mathrm{O}$ que o educador criou foi uma pedagogia do oprimido, não uma pedagogia para ele, mas dele ${ }^{29}$. Ao contrário do que seus detratores afirmam, a maneira freiriana de educar não postula um "sábio emancipador" que carrega "todo" o conteúdo da liberdade e que, ao serem introjetados nas mentes dos oprimidos, estes se libertam. Os caminhos da liberdade são construídos por eles e são os oprimidos que se libertam. São os oprimidos, e somente eles, que tomam as rédeas para sua emancipação, como

Quem, melhor que os oprimidos, se encontrará preparado para entender o significado terrível de uma sociedade opressora? Quem sentirá, melhor que eles, os efeitos da opressão? Quem, mais que eles, para ir compreendendo a necessidade da libertação? Libertação a que não chegarão pelo acaso, mas pela práxis de sua busca; pelo conhecimento e reconhecimento da necessidade de lutar por ela ${ }^{30}$.

A luta pedagógica freiriana está centrada em uma práxis educativa que suprassuma (aufhebung) o "parasita" opressor do oprimido. Não é pela via de um conhecimento externo e distante dos excluídos, e nem pela vereda de um certo "romantismo" em que é idealizado o enraizamento da cultura oprimida, mas é por meio dela e com ela. Da mesma maneira, não tem como propósito apenas refletir a realidade, e sim tensioná-la reflexivamente, criando e recriando novos caminhos para a prática da liberdade. E mais, o caminho da liberdade está tanto para os oprimidos, quanto para os opressores. Isso quer dizer que seu objetivo não é destruir e livrar-se dele. É, no entanto, destituir simbolicamente o Outro de si. De maneira hegeliana, "a verdade do opressor reside na consciência do oprimido"31.

E aí está a grande tarefa humanista e histórica dos oprimidos - libertar-se a si e aos opressores. Estes, que oprimem, exploram e violentam, em razão de seu poder, não podem ter este poder, a força de libertação dos oprimidos nem de si mesmos. Só o poder que nasça da debilidade dos oprimidos será suficientemente forte para libertar a ambos ${ }^{32}$.

A força do oprimido está na sua possibilidade de romper com o conteúdo da opressão, e sublimando-o de si e de sua realidade. Wendy Brown sublinha esta
28. Ibidem, p. 19-20.

29. FIORI, Ernani Maria. Prefácio. In: FREIRE, Paulo. Pedagogia do oprimido. 17. ed. Rio de Janeiro: Paz e Terra, 2005. p. 7-29

30. FREIRE, Paulo. Pedagogia do... Op. cit., p. 20

31. Ibidem, p. 6.

32. Ibidem, p. 20. 
33. BROWN, Wendy. States of injury: power and freedom in late modernity. New Jersey: Princeton University Press, 1995, p. 7.

34. MARX, Karl. O capital: crítica da economia política. 2. ed. São Paulo: Boitempo, 2017. v. 1, p. 134.

35. FREIRE, Paulo. Pedagogia do... Op. cit., p. 23.

36. Idem. Pedagogia do... Op. cit., p. 48.

37. O texto Paulo Freire: o patrono do atraso (além sintetizar muito a camada imaginária dos detratores que a culpa do desastre avaliativo da educação, o desempenho no Pisa, é culpa de Freire) caí nesse mesmo equívoco ao dizer que: "E se podemos dar um nome para essa tragédia cultural e educacional no Brasil certamente seria Paulo Freire. Considerado - patrono da educação é autor da obra Pedagogia do Oprimido, raiz de todo o problema. Através dessa pedagogia as crianças foram educadas a inverter lógicas, transgredir padrões, desrespeitar leis de forma velada e, principalmente, a colocar a culpa no 'sistema'. Sistema esse opressor ao qual todos devem se rebelar. Onde professor não é mais autoridade dentro da sala e sim alguém que pode aprender com o aluno. Onde não existe mais certo e errado e sim pontos de vista diferentes. Onde tudo é relativo. É o famoso método sócio construtivista onde só existem dois elementos: o aluno e o resto do mundo. Esse método triste e ironicamente desconstruiu a base educacional brasileira". OLIVEIRA, Vinicius André de. Paulo Freire: o patrono do atraso. Agrolink, [s. I.], 15 ago. 2018. Disponível em: https://www.agrolink.com. $\mathrm{br} /$ colunistas/coluna/paulo-freire---o-patrono-do-atraso_410039.html. Acesso em: 28 abr. 2021.

38. FREIRE, Paulo. Pedagogia do... Op. cit., p. 23. mesma lógica dialética, que, na tomada de consciência da opressão, a primeira reação dos oprimidos é imaginar um mundo privado do Outro opressor: os trabalhadores imaginam um mundo sem o burguês explorando o seu suado trabalho, as feministas imaginam um mundo sem homens, os negros imaginam um mundo sem brancos etc. ${ }^{33}$. No entanto, esta postura está mais para um "ativismo ingênuo", semelhante à fantasia de adolescentes rebeldes que imaginam que gozarão da vida por "completo" quando se livrarem dos seus pais. $\mathrm{O}$ engano não está na radicalidade desse desejo; ao contrário, o equívoco está em não ser radical o suficiente. Todas essas categorias (trabalhador, feminista, negro e até adolescente) são mediadas pelo Outro, não havendo trabalhador sem capitalista, feminista sem machismo e, assim por diante. Ou, como dizia Marx, "este homem é rei porque outros homens se relacionam com ele como súditos. Inversamente, estes creem ser súditos porque ele é rei” ${ }^{44}$. De outro modo, para nos livrarmos do Outro opressor, devemos transformar o conteúdo de nossa própria posição.

Também não basta apenas sabermos da dialética da opressão e apenas compartilhá-la. É preciso enfatizarmos a entrega de sua práxis libertadora ${ }^{35} \mathrm{e}$ explicar que seu caminho é longo e árduo. A metáfora do parto está cravada neste sentido de que a criação de uma educação como prática libertadora é um processo contínuo de desenvolvimento, entre lutas vencidas e perdidas, perdas e ganhos que estão relacionados tanto aos antagonistas, quanto entre nós e em nós. O caminho da emancipação é difícil, mas necessário. Apesar de ser verdade que autonomia é construída de maneira penosa, com conteúdos que, a princípio, acometem em dependência, a forma insiste que algo foi excluído, e desta exclusão a liberdade aparece refletindo que o espaço antes ocupado pela dependência ao Outro, agora reflexiona-se em uma autonomia fundada na responsabilidade ${ }^{36}$.

É por isso que é estranha a crítica que a educação como prática de liberdade incita os educandos ao subjetivismo. É comum ver nessa leva de detratores que a pedagogia de Freire incentiva os relativismos ${ }^{37}$, ou que esta não reconhece a objetividade os valores (bem e mal), ou, em alguns casos, levam ao "pé da letra" trechos como: "ninguém educa ninguém", "ninguém liberta ninguém", tirando as frases de contexto para parecer que é um puro subjetivismo. De maneira oposta, Freire dizia que:

Não se pode pensar em objetividade sem subjetividade. Não há uma sem a outra, que não podem ser dicotomizadas. A objetividade dicotomizada da subjetividade, a negação desta na análise da realidade ou na ação sobre ela, é objetivismo. Da mesma forma, a negação da objetividade, na análise como na ação, conduzindo ao subjetivismo que se alonga em posições solipsistas, nega a ação mesma, por negar a realidade objetiva, desde que esta passa a ser criação da consciência. Nem objetivismo, nem subjetivismo ou psicologismo, mas subjetividade e objetividade em permanente dialeticidade ${ }^{38}$.

As afirmações "ninguém educa ninguém”, “ou ninguém liberta ninguém” significam que ninguém se educa a si mesmo, ou se liberta sozinho, que "os 
homens se educam em comunhão, mediatizados pelo mundo. Mediatizados pelos objetos cognoscíveis que, na prática 'bancária', são possuídos pelo educador que os descreve ou os deposita nos educandos passivos ${ }^{39}$. Isso não afirma haver exclusão do saber do mestre, mas, uma dialética entre docente e discente. Contrário à postura "bancária" (transferência de conhecimento), o educador crítico está lá para aprender a ensinar: primeiro o educador deve adentrar o contexto dos estudantes porque o conteúdo do seu saber (conhecimento acadêmico) é negado pelo contexto específico dos educandos (a condição material e cultural), mas, ao ser negado, volta de uma forma diferente (negação da negação), não de maneira relativista, mas em relação àquele contexto específico. Nesse diálogo, o educador convida o educando a participar de uma jornada de construção de conhecimento, em que prioridade não é conhecimento a priori do educador, mas conhecimento que será construído juntos e que o estudante será o protagonista dessa história.

O que a educação bancária prioriza é a transferência do saber do mestre, sem colocá-lo em contexto com a realidade dos educandos. De forma contrária, a educação crítica movimenta o conhecimento do "em si" ao "para si" e desperta nos educandos o gosto pela investigação. Antes aquele conhecimento que parecia ser abstrato e demasiadamente distante, agora reflexiona-se de maneira a pensar o nosso lugar: "quem somos e qual é o nosso lugar ao Outro?" A autonomia da educação está em despertar o interesse dos professores e estudantes ao conhecimento, não um conhecimento "acientífico"; muito pelo contrário, um conhecimento que está a refletir e criticar a sua realidade. E é por esta razão que:

[...] ensinar não se esgota no "tratamento" do objeto ou do conteúdo, superficialmente feito, mas se alonga à produção das condições em que aprender criticamente é possível. E essas condições implicam ou exigem a presença de educadores e de educandos criadores, instigadores, inquietos, rigorosamente curiosos, humildes e persistentes. Faz parte das condições em que aprender criticamente é possível a pressuposição por parte dos educandos de que o educador já teve ou continua tendo experiência da produção de certos saberes e que estes não podem a eles, os educandos, ser simplesmente transferidos. Pelo contrário, nas condições de verdadeira aprendizagem os educandos vão se transformando em reais sujeitos da construção e da reconstrução do saber ensinado, ao lado do educador, igualmente sujeito do processo. Só assim podemos falar realmente de saber ensinado, em que o objeto ensinado é apreendido na sua razão de ser e, portanto, aprendido pelos educandos ${ }^{40}$.

\section{CONSIDERAÇÕES FINAIS}

A educação libertadora dispõe de uma práxis que incentiva um horizonte de condições por meio das quais o oprimido pode, reflexivamente, conquistar sua emancipação e, assim, ser sujeito de sua história. Seu juízo sobre a realidade não prioriza apenas o ensino que reflete e sistematiza, mas que problematiza

39. Ibidem, p. 44 40. Idem. Pedagogia do... Op. cit., p. 14-15. 
de forma partidária o Outro. Do Real, que vem a ser os "pontos de vista", a "educação crítica" não teme em dizer o seu nome, quais são suas propostas, suas premissas e a quem está endereçada. Ao contrário de se esconder nas aparências da "imparcialidade", Freire nos ensina que devemos nos posicionar, o que significa respeitar os educandos:

Em nome do respeito que devo aos alunos não tenho por que me omitir, por que ocultar a minha opção política, assumindo uma neutralidade que não existe. Esta, a omissão do professor em nome do respeito ao aluno, talvez seja a melhor maneira de desrespeitá-lo. O meu papel, ao contrário, é o de quem testemunha o direito de comparar, de escolher, de romper, de decidir e estimular a assunção deste direito por parte dos educandos ${ }^{41}$.

Da lacuna do Real que fere a nossa realidade, rejeitamos a neutralidade não apenas porque é uma crença ingênua, mas porque, antes de tudo, é uma posição antiética. Quando não nos posicionamos criamos uma fantasia de defesa contra o Real, embora a realidade seja movimentada pelas contingências que sofrem "curtos-circuitos" com a ação e a mediação humana. Isso significa que temos responsabilidades perante a nossa realidade, e, quanto às contingências, não devemos ser apenas espectadores, ou cairmos nos fatalismos, mas, sim, atuarmos de forma engajada nas aberturas do Real, nas novas possibilidades de realidade.

Da mesma forma, o legado de Freire, e seu espectro, devem ser significados pelas demandas do presente. $\mathrm{O}$ que o educador teria a nos dizer sobre o atual contexto de nosso cenário político? O quê, ou em quê, a sua pedagogia tem a nos ensinar sobre educar e aprender? Quais são as potencialidades emancipatórias de seu "método"? Quais são os seus limites? Todas estas questões devem ser analisadas e respondidas de maneira retroativa, ou seja, levando em conta o espectro de Freire em tensão ao movimento das necessidades presentes de cada contexto, e não uma entidade mística que ensina aos seus fiéis seguidores o caminho da salvação.

Hoje o espectro de Freire nos assombra com sua voz incômoda, porque, como diria Derrida ${ }^{42}$, o espectro tem as possibilidades de romper os limites do tempo e, assim, cobrar dos vivos uma dívida de justiça em relação às memórias

41. Ibidem, p. 36-37.

42. DERRIDA, Jacques. Espectros de Marx: el estado de la deuda, el trabajo del duelo y la nueva internacional. Madrid: Trotta, 1998.

43. LÖWY, Michael. Walter Benjamin: aviso de incêndio - uma leitura das teses "Sobre o conceito de história". São Paulo: Boitempo, 2005, p. 48

44. Ibidem, p. 64.

45. Ibidem, p. 48 esquecidas. Os esquecidos não são apenas de nosso presente, mas, também, os excluídos da história. Como dissertou Benjamin, a história é permeada por vozes excluídas que pedem redenção no presente: "Não nos afaga, pois, levemente um sopro de ar que envolveu os que nos precederam"43. Elas se acendem e se apagam, quão um objeto que atua de maneira "autônoma e parcial" na realidade: "uma imagem célebre e furtiva, visível apenas no tempo de um relâmpago"44. Sempre escapa algo da história e o processo de significação ao Outro deixa um resto não significado na realidade, uma voz que ainda não adentrou ao corpo da linguagem, daí a sequência: "Não ressoa nas vozes a que damos ouvido um eco das que estão, agora, caladas?" ${ }^{25}$. Pensamos que o espectro de Freire deve ser pensado da mesma maneira, ou seja, as "vozes parciais" do educador (que 
Paulo Freire e o legado de uma educação partidária em prol da práxis do oprimido

- Lucia de Fatima Valente e Thalles Valente de Paiva

perambulam assombrando a nossa tecitura normativa de realidade), assim como seu legado, devem ser significados à práxis dos oprimidos. Para lembrar àqueles que tentam apagar as vozes dos oprimidos, elas voltarão no Real, atormentando a realidade presente.

\section{REFERÊNCIAS BIBLIOGRÁFICAS}

BROWN, Wendy. States of injury: power and freedom in late modernity. New Jersey: Princeton University Press, 1995.

DERRIDA, Jacques. Espectros de Marx: el estado de la deuda, el trabajo del duelo y la nueva internacional. Madrid: Trotta, 1998.

FIORI, Ernani Maria. Prefácio. In: FREIRE, Paulo. Pedagogia do oprimido.17. ed. Rio de Janeiro: Paz e Terra, 2005. p. 7-22.

FREIRE, Paulo. A importância do ato de ler. São Paulo: Cortez, 1989.

FREIRE, Paulo. Pedagogia da autonomia: saberes necessários à prática educativa. São Paulo: Paz e Terra, 2002.

FREIRE, Paulo. Pedagogia do oprimido. 17. ed. Rio de Janeiro: Paz e Terra, 1987.

GADOTTI, Moacir. Convite à leitura de Paulo Freire. 2. ed. São Paulo: Scipione, 2004.

GADOTTI, Moacir. O IPF e o legado de Paulo Freire. Revista de Ciências da Educação, Lorena, v. 2, n. 3, p. 231-241, 2000.

GADOTTI, Moacir. Por que continuar lendo Freire? Buenos Aires: Clacso, 2003.

IACONNELLI, Vera. Risco mimimi em números. Folha de S.Paulo, São Paulo, 9 abr. 2019. Disponível em: https://wwwl.folha.uol.com.br/colunas/veraiaconelli/2019/04/risco-mimimi-em-numeros.shtml. Acesso em: 15 abr. 2021.

INVESTIGAÇÃO aponta assessor de Bolsonaro como responsável por página de fake news derrubada pelo Facebook. G1, Rio de Janeiro, 8 jul. 2020. Disponível em: https://g1.globo.com/economia/tecnologia/ noticia/2020/07/08/investigacao-aponta-assessor-de-bolsonaro-comoresponsavel-de-pagina-de-fake-news-derrubada-pelo-facebook.ghtml. Acesso em: 27 out. 2021.

LÉVI-STRAUSS, Claude. Antropologia estrutural. São Paulo: Cosac Naify, 2008.

LÖWY, Michael. Walter Benjamin: aviso de incêndio - uma leitura das teses "Sobre o conceito de história”. São Paulo: Boitempo, 2005.

LÖWY, Michael. Marxismo contra positivismo. São Paulo: Cortez, 2018.

MARX, Karl. O capital: crítica da economia política. 2. ed. São Paulo: Boitempo, 2017, v. 1. 
O GLOBO. 'Economist' critica a era da 'pós-verdade' na política. O Globo, Rio de Janeiro, 8 out. 2016. Disponível em: https://oglobo.globo.com/ brasil/economist-critica-era-da-pos-verdade-na-politica-20258867. Acesso em: 27 out. 2021.

OLIVEIRA, Vinicius André de. Paulo Freire: o patrono do atraso. Agrolink, [s. l.], 15 ago. 2018. Disponível em: https://www.agrolink.com.br/colunistas/coluna/ paulo-freire-o-patrono-do-atraso_410039.html. Acesso em: 28 abr. 2021.

PENNA, Fernando de A. A escola sem partido como chave do fenômeno educacional. In: FRIGOTTO, Gaudêncio (org.). Escola “sem" partido: esfinge que ameaça a educação e a sociedade brasileira. Rio de Janeiro: LPP/ UERJ, 2017. p. 35-48.

SAVIANI, Demerval. A crise política no Brasil, o golpe e o papel da educação na resistência e na transformação. In: LUCENA, Carlos; PREVITALI, Fabiane Santana; LUCENA Lurdes. A crise da democracia brasileira. Uberlândia: Navegando, 2017. p. 215-232

SOUZA, Marcele; TOLEDO, Giuliana de. Legado de Paulo Freire é defendido por uns e odiado por outros. Revista Galileu, Rio de Janeiro, 2 maio 2017. Disponível em: https://revistagalileu.globo.com/Revista/ noticia/2017/05/legado-de-paulo-freire-e-defendido-por-uns-e-odiadopor-outros.html\#: :text=\%E2\% 80\%9CTudo \% 20que $\% 20$ a $\% 20$ gente $\% 20$ faz,\%E2\%80\%9D\%2C\%20orgulha-se\%20Nogueira. Acesso em: 28 abr. 2021.

SZONDI, Peter. Teoria do drama moderno. São Paulo, Cosac Naify, 2001.

ŽIŽEK, Slavoj. A marioneta e o anão: o cristianismo entre perversão e subversão. Lisboa: Relógio d'Água, 2006.

ŽIŽEK, Slavoj. Um mapa da ideologia. Rio de Janeiro: Contraponto, 1996. 